\title{
Degradative Variation of Nitrogen Concentration during Channels of Paddy Field Drainage in Estuary Area
}

\author{
Xianchao $\mathrm{Ji}^{1, \text { a }}$, Haibo $\mathrm{Li}^{2, \mathrm{~b}}$, Hong Wang ${ }^{1, \mathrm{c}}$ and Yanyan $\mathrm{Yu}^{1, \mathrm{~d}}$ \\ ${ }^{1}$ School of environment, Shenyang University, Shenyang, Liaoning 110044, China; \\ ${ }^{2}$ School of Resources and Civil Engineering, Northeast University, Shenyang, Liaoning 110004 , \\ China. \\ aJXC199018@163.com, blihaibo@126.com, cwangh51@126.com, dyyy9817@126.com
}

Keywords: Nitrogen, paddy fields drainage, different fertilization period, ditches system.

\begin{abstract}
To effectively reduce the effects of nitrogen pollutants on water environment. Selecting the rice-growing area of Liaohe River estuary in Panjin City of Liaoning Province as the research object, Different sections and the different stages of a single fertilization in ditch is sampled to measure and analyze the three nitrogen of ditch system in different stages of fertilization; the paper investigated the reductive variation of nitrogen concentration in paddy fields drainage. The results show that: Ammonia nitrogen concentration is on the decline in a whole, however, ammonia nitrogen was relaxedly increased in different periods, due to the variation of northern rice area is obvious in different stages of fertilization, fluctuations in paddy fields drainage on ammonia nitrogen. Nitrate nitrogen at the early stage of the basal period changes gently, after rising slowly towards stability. Nitrate nitrogen is decreasing along the way in Rice fertilizer period, but the trend is not obvious. At earing fertilizer period of Nitrate nitrogen is Firstly decline and then stabilize. The decision is ditches sediment microbial activity.
\end{abstract}

\section{Introduction}

Nitrogen is irreplaceable components needed for living system, is an important element of life, and is also the basis to promote the development of agricultural ecological factors [1]. In order to improve the production capacity of the rice-growing area, Over-use Nitrogen fertilizer increasingly crop yields, but failing to grasp optimal management methods of fertilization on timely and right amount lead to the average utilization rate of nitrogen fertilizer is very low. And "surplus" Nitrogen in rice field under the scour of precipitation or irrigation, the way is erosion through the surface runoff and Paddy fields drainage and leakage of underground to formation of agricultural non-point source pollution, cause the eutrophication of water bodies. The effects is caused by agricultural non-point source pollution on water environment, international and domestic academics launched a lot of researches in allusion to nitrogen loss of Rice paddies water table and ditch water back. Peng Shi-zhang is based on the TN, $\mathrm{NH}_{4}{ }^{+}-\mathrm{N}, \mathrm{NO}_{3}{ }^{-}-\mathrm{N}$ monitoring in drainage of nitrogen concentration and import and export of wetlands, researching the nitrogen concentration variation of farmland drainage in irrigation and drainage measures and ditch pond wetland[2]; Bonaiti $\mathrm{G}$ by comparing nitrate nitrogen concentration of farmland drainage ditches and groundwater under four different drainage and irrigation schemes were analyzed the influence of underground irrigation to reduce nitrogen $\operatorname{loss}[3]$.

Ditches as an important component of the paddy field ecosystem, having the dual effect of drainage and wetland system[4]. Therefore, this paper investigate the different fertilization stage of nitrogen concentration variation in ditch system in under the effect of natural conditions, The research to the correct evaluation of paddy water runoff to the water pollution on the influence of the outside world, having important significance for putting forward the effective method to control and decision. for this purpose, This study selected Liaohe estuary paddy production area in Shuangtaizi District of Panjin City as the research object, researches on the paddy fields drainage of different 
fertilization stage, under normal environmental impact are analyzed on basal period, tillers stage fat, earing fertilizer period after three stages of fertilizing nitrogen concentration variation characteristics.

\section{Materials and Methods}

\subsection{General Situation of Test Area.}

The study area is located in Panjin city of Liaoning Province-Shuangtaizi River tributaries of the Liaohe River Valley paddy planting area, selected the area to improve the structure of the eco-logical environment of paddy ditch $\left(41^{\circ} 06\right.$ ' 8.59 " N, 121 51' 36.51" E) as the research object, the experimental area ditch belongs to the low-lying flat for a retreat of the sea, alluvial plain, elevation for the $3 \mathrm{~m}$. The region belongs to the warm temperate zone continental semi-humid monsoon climate. The cold period is long, windy plains, wet in east and dry in west, rainfall concentrated, abundant sun-shine, four distinct seasons. For many years, the average temperature from downstream to upstream plain mountain area gradually reduced, the temperature also interannual is high. Annual average temperature $9.3^{\circ} \mathrm{C}$, the annual total rainfall of 535.8 millimeters, the annual total sunshine hours for 2738.8 hours, annual frost-free period 204 days. The study areas were soil types for the meadow soil, $0 \sim 20 \mathrm{~cm}$ arable layer soil physical and chemical properties: $\mathrm{pH} 8.2$, Organic matter $22.57 \mathrm{~g} \cdot \mathrm{kg}^{-1}$ 、 Total nitrogen $1.42 \mathrm{~g} \cdot \mathrm{kg}^{-1}$ 、 Available phosphorus $21.61 \mathrm{mg} \cdot \mathrm{kg}^{-1}$ 、 Available potassium $164.22 \mathrm{mg} \cdot \mathrm{kg}^{-1}$.

\subsection{Design and Sample Test.}

The experiment of planting area in Shuangtaizi district of Panjin City carry out research on the attenuation variation of nitrogen concentration in paddy fields drainage during April 2014. The variation features of nitrogen concentration of paddy fields drainage in ditch during different fertilizing stage is analyzing, Selecting typical single inlet ditches as the research object, the ditch total length about $450 \mathrm{~m}$, In the ditches along the water flow direction every $90 \mathrm{~m}$ set a monitoring section, Each section in different phases of fertilization (basal period(N1), tillers stage fertilizer(N2), earing fertilizer period (N3)) is sampling, It will be collected water samples in $500 \mathrm{ml}$ of polyethylene bottles during different phases of fertilization, with $10 \%$ of dilute sulphuric acid adjust water for $\mathrm{pH}<2$, and save in $4^{\circ} \mathrm{C}$ refrigerator, as well as suppress the sample microbial activity. And as soon as possible to the total nitrogen, ammonia nitrogen, nitrate nitrogen, the index of water for laboratory analysis. Determination of test project: TN using potassium per sulfate oxidation-UV Spectrophotometer; $\mathrm{NH}_{4}{ }^{+}-\mathrm{N}$ uses Nessler's reagent spectrphotometric method, $\mathrm{NO}_{3}{ }^{-} \mathrm{N}$ by UV spectrophotometer.

\section{Results and Discussions}

\subsection{The Variation Characteristics of Total Nitrogen in Different Fertilization Stage.}

Figure 1 is the variation of total nitrogen in different ditches section, water inlet total nitrogen concentration of $3.95 \sim 4.52 \mathrm{mg} \cdot \mathrm{L}^{-1}$, outlet concentration of $2.58 \sim 4.16 \mathrm{mg} \cdot \mathrm{L}^{-1}$. Every section of different fertilization stage ditches fitting the experimental results: the results are shown in table 1. From the fitting results of table 1 and figure 1, the total nitrogen along the canal length is two times polynomial curve, and has good correlation. The total nitrogen showed decreased and then increased in basal period, during the tillers stage fertilizer and earing fertilizer period total nitrogen diminishing trend along the whole; Total nitrogen in paddy water process is not has declined but increase significantly, and the change rule of total nitrogen is not constant. tillers fertilizer stage and earing fertilizer is on the decline because of ditches can effectively intercept nitrogen, but after the basal period of section 4 total nitrogen might be increase due to the north at this point in the thawing period, stored in the ditches sediment nitrogen, lead to the rise of temperature, makes the nitrogen release and enter the result in higher total nitrogen in water. 


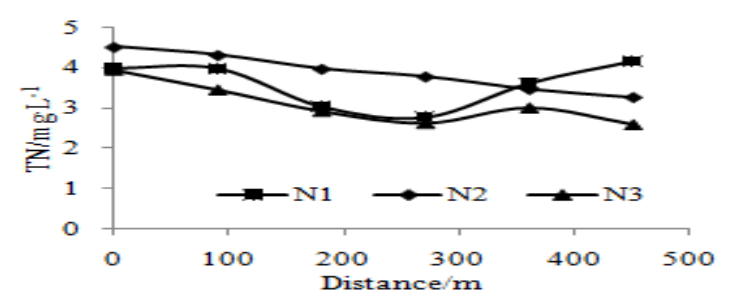

Fig. 1 TN changes along the trench length

\subsection{The Variation Characteristics of Ammonia Nitrogen in Different Fertilization Stage.}

As you can see from Figure 2, the water inlet ammonia concentration was $1.5 \sim 2 \mathrm{mg} \cdot \mathrm{L}^{-1}$, outlet concentration of $0.5 \sim 1.5 \mathrm{mg} \cdot \mathrm{L}^{-1}$, the section of different fertilization stage ditch experimental results were fitted, as shown in table 1. From Figure 2 and table 1 fitting results, ammonia nitrogen along the trench length is the two times polynomial curve, and has a good correlation. ammonia concentration was increased slowly, then decreased rapidly in ditch during the Basal period, in the ditch three section when reaching the lowest for $0.5 \mathrm{mg} \cdot \mathrm{L}^{-1}$, then gradually increase. Ammonia nitrogen concentration attain peak in section 1during the tillers stage fertilizer and earing fertilizer period, after declining along the path. Ammonia nitrogen in section 5 had slight fluctuations along the cross and overall change is on the decline.

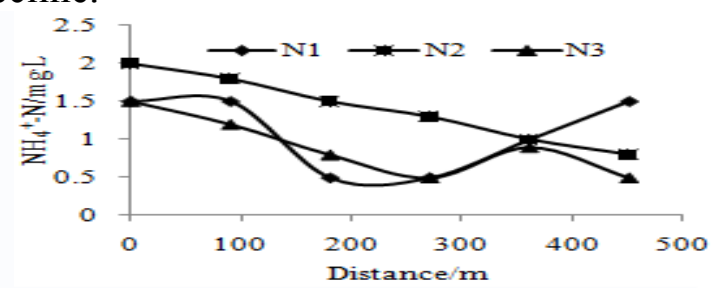

Fig. $2 \mathrm{NH}_{4}{ }^{+}-\mathrm{N}$ changes along the trench length

The peak of ammonia nitrogen concentration in basal period and earing fertilizer period is lower than the tillers stage fertilizer, because of the northern rice fields are alternative period of season in basal period and earing fertilizer period, The temperature fluctuation is obvious, the range of temperature is bigger, windy drought and quantity of ammonia volatilization is big, These factors make the concentration of ammonia nitrogen in drainage to low. Tillers stage fertilizer is June, this moment rainfall is abundant, accumulated a lot of water in surface and ditches make increase the amount of water in paddy fields drainage and improve flow speed, a large amount of nitrogen loss by the surface runoff, which leads to nitrogen concentration on the high side of paddy fields drainage, and the main forms of the output nitrogen is ammonia nitrogen in ditch system. So ammonia nitrogen is slightly higher. Basal period in the end of the ditch section of ammonia nitrogen is higher than the tillers stage fertilizer and earing fertilizer period. Because of ditch system is in the midst of the thawing period, it will release part of nitrogen during this time, raising the point of ammonia nitrogen.

Table 1 the change fitting equation of drainage water in paddy field on $\mathrm{N}$ concentration along the way

\begin{tabular}{cccc}
\hline Item & Period & Regression Equation & Coefficient \\
\hline \multirow{2}{*}{$\mathrm{TN}$} & Basal & $\mathrm{y}=0.176 \mathrm{x}^{2}-1.25 \mathrm{x}+5.29$ & $\mathrm{R}^{2}=0.73$ \\
& Tillering & $\mathrm{y}=0.002 \mathrm{x}^{2}-0.27 \mathrm{x}+4.81$ & $\mathrm{R}^{2}=0.99$ \\
& Topdressing & $\mathrm{y}=0.074 \mathrm{x}^{2}-0.76 \mathrm{x}+4.62$ & $\mathrm{R}^{2}=0.88$ \\
$\mathrm{NH}_{4}{ }^{+}-\mathrm{N}$ & Basal & $\mathrm{y}=0.152 \mathrm{x}^{2}-1.11 \mathrm{x}+2.65$ & $\mathrm{R}^{2}=0.73$ \\
& Tillering & $\mathrm{y}=-0.0027 \mathrm{x}+2.01$ & $\mathrm{R}^{2}=0.99$ \\
& Topdressing & $\mathrm{y}=0.048 \mathrm{x}^{2}+0.52 \mathrm{x}+1.97$ & $\mathrm{R}^{2}=0.82$ \\
& Basal & $\mathrm{y}=0.022 \mathrm{x}^{2}-0.13 \mathrm{x}+0.96$ & $\mathrm{R}^{2}=0.39$ \\
$\mathrm{NO}_{3}{ }^{-}-\mathrm{N}$ & Tillering & $\mathrm{y}=0.002 \mathrm{x}^{2}-0.02 \mathrm{x}+0.41$ & $\mathrm{R}^{2}=0.89$ \\
& Topdressing & $\mathrm{y}=0.026 \mathrm{x}^{2}-0.25 \mathrm{x}+0.66$ & $\mathrm{R}^{2}=0.95$ \\
\hline
\end{tabular}




\subsection{The Variation Characteristics of Nitrate Nitrogen in Different Fertilization Stage.}

Each section of nitrate nitrogen in different fertilization stage are always fluctuate in the influence of natural environment, it can be seen from Figure 3, Due to geographic position of each section exist difference. Nitrogen at the same time the output of the different sections is quite distinct from each other. Nitrate nitrogen inlet concentration of $0.39 \sim 0.82 \mathrm{mg} \cdot \mathrm{L}^{-1}$, the outlet concentration of $0.08 \sim 1.00 \mathrm{mg} \cdot \mathrm{L}^{-1}$, the section of the different fertilization stage ditch experimental results were fitted, as shown in table 1. The fitting result from Figure 3 and table 1, nitrate nitrogen along the trench length is two times polynomial curve, and the correlation of nitrate nitrogen is not very high in basal period, the correlation between the other two periods is very good. The early stage of the variation of nitrate nitrogen is gently during basal period, and then quickly fell to a low of $0.63 \mathrm{mg} \cdot \mathrm{L}^{-1}$, after rising slowly reaching stability. The variation of nitrate nitrogen is decreased progressively along the path during tillers stage fertilizer, but the variation tendency is not obvious. Nitrate nitrogen is firstly decline and then stabilizes during tillers stage fertilizer.

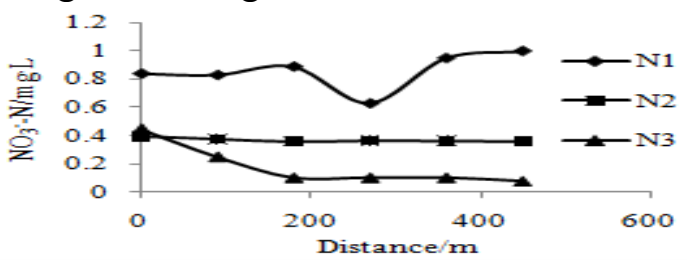

Fig. $3 \mathrm{NO}_{3}{ }^{-}-\mathrm{N}$ changes along the trench length

Nitrate nitrogen in basal period is obviously higher than tillers stage fertilizer and earing fertilizer period, Because of the basal period is the early stage of the rice growth, the northern region is rising of temperature stage from May to June, sediment microbial activity is low in ditches, nitrification and denitrification are weaker, Nitrate ion has good stability at the same time, not easy to adsorb, In tillers stage fertilizer and earing fertilizer, microbial under the condition of the nitrogen source is sufficient blooms, nitrification and denitrification of leading role, nitrate nitrogen by denitrification reaction generated nitrogen volatilization, so the basal period of nitrate is higher than the tillers stage fertilizer and earing fertilizer.

\section{Conclusion}

(1) The total nitrogen along the canal length is two times polynomial curve, and has good correlation. Total nitrogen is on the decline along the path in a whole, but part of total nitrogen is increased, the variation regularity of total nitrogen is not always declined, it can be affected by the surrounding environment to change.

(2) Through the different phases of fertilization ditches fitting of each section of the experiment results, the ammonia nitrogen along the canal length is two times polynomial curve changes, it is concluded that ammonia nitrogen overall change is on the decline.

(3) Different stages of fertilization of each section of nitrate in under the influence of natural environment condition is always fluctuated, the nitrate nitrogen along the canal length is two times polynomial curve changes, nitrate nitrogen is firstly declined and then increased in basal period; The variation of nitrate nitrogen is decreased progressively along the path during tillers stage fertilizer, but the variation tendency is not obvious. Nitrate nitrogen is firstly decline and then stabilizes during tillers stage fertilizer.

\section{Acknowledgements}

This work has been financially supported by the Major Science and Technology Program for Water Pollution Control and Treatment (Nos. 2013ZX07202-007 and 2014ZX07201-009-04), Science and Technology Program of Liaoning Province (Nos. 2011229002 and 2013229012), Program for Distinguished Young Scholar of Liaoning Province (LJQ2012102), the Major Science and Technology Project of Guizhou Province(2012-6014). 


\section{References}

[1]. Weijin Yan, Chengqing Yi, Pu Sun, et al. Phosphorus and nitrogen transfers and runoff losses from rice field wetlands of Chaohu Lake. Chinese Journal of Applied Ecology. Vol. 3(1999) No. 10, p. 312-316.

[2]. Peng Shizhang, Zhang Zhengliang, Luo Yufeng, et al. Variation of nitrogen concentration in drainage water from paddy fields under controlled irrigation and drainage. Vol. 25 (2009) No. 9, p. 21-26.

[3]. Bonaiti G, Borin M. Efficiency of controlled drainage and subirrigation in reducing nitrogen losses from agricultural fields. Agricultural Water Management Vol. 2(2010) No. 11, p. 343-352.

[4]. XIE Hong-Mei, ZHU Bo. Research progress on N movement between soil and water interface in agro-ecosystem. Chinese Journal of Eco-Agriculture. Vol. 12 (2004) No. 10, p. 122-125. 